\title{
Management Pathway for Older Patients with Prostate Cancer
}

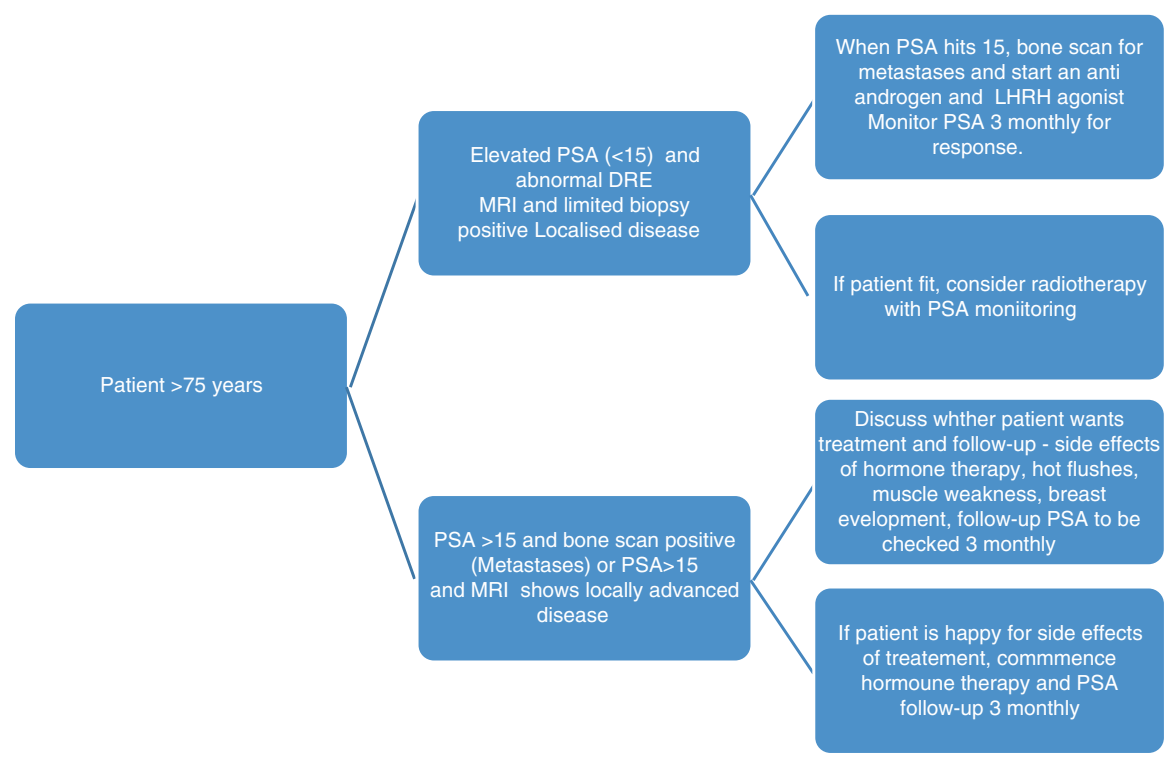

\section{Suggested Reading}

AUA Guidelines, Early Detection of Prostate Cancer, 2015.

EAU Guidelines on Prostate Cancer, 2018.

NICE Guidance NG 2, 2008. 